\title{
DESGRIPTION OF ESKERS AND KAMES IN GÅSHAMNÖYRA AND ON BUNGEBREEN, SOUTH OF HORNSUND, VESTSPITSBERGEN
}

\author{
By Stefan Jewtuchowicz \\ (Instytut Geografii, P.A.N., Łódź, Poland)
}

As a member of the Polish scientific expedition to Spitsbergen during the summer of I959, the writer collected some observations on forms which occur in the area in front of Gassbreen and on Bungebreen. Eskers and kames occur here in two different environments. In the vicinity of Gåsbreen they are present in areas already left by the retreating ice tongue, whereas the eskers and kames of Bungebreen are spreading in areas which are still ice-covered and are now emerging from the ice as a result of ablation (Fig. I).

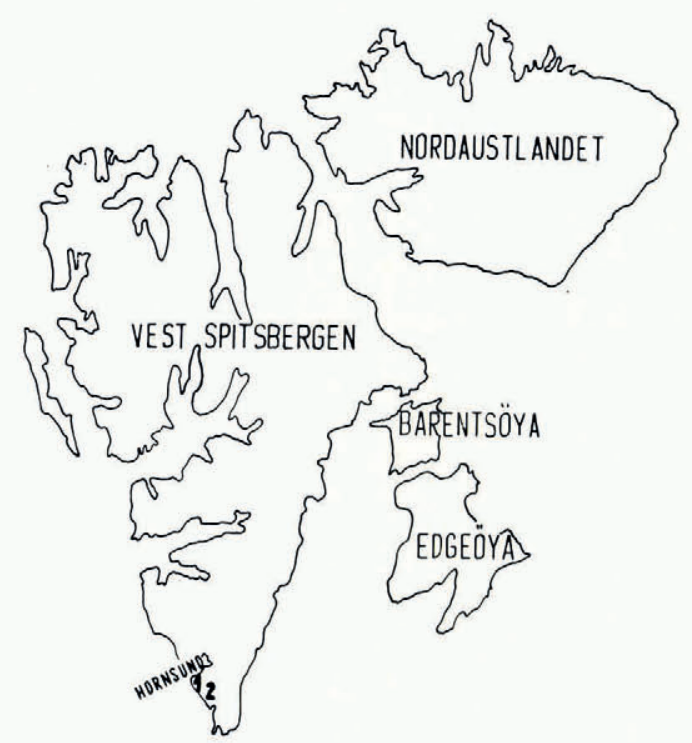

Fig. I. Sketch map of Svalbard to show the location of the area investigated in Vestspitsbergen. 1. Gäshamnöyra; 2. Bungebreen

Melt water, flowing from the front of Gåsbreen, continually destroys all the forms occurring within the range of its activity and covers them with the transported debris. A result of this process is the formation of the Gåshamnöyra outwash plain. In spite of the fact that there is extreme melt-water activity in the proximal part of Gåshamnöyra, the still undestroyed and uncovered eskers, kames, end moraines, channels and kettles formed during the glacier's halt there can be easily seen.

In the course of this investigation the shape, size and situation of the eskers and kames, and whether they occur in groups or singly, were considered. With regard to the structure, the nature and origin of the material, its grain-size, stratification and the sequence of the layers were investigated.

The Gåshamnöyra eskers form a dendritic pattern (Fig. 2). The longest esker has a tortuous course but the shorter ones are straight. The largest esker has a length of I86 m., it trends in a south-east to north-west direction and is oriented obliquely to the present glacier margin. On its southern side, whence the glacier flowed, the esker merges into other smaller ones ranging from 90 to $32 \mathrm{~m}$. in length. These eskers are associated with channels and kettles. 
The esker of Bungebreen is gradually emerging as the ice surface on either side melts. It occurs near the lateral moraine and the interconnecting channel, through which melt water drains down from the glacier to the outwash plain (Fig. 3). The elevation of the esker above the ice surface is about $4 \mathrm{~m}$. and the part of the esker above the ice extends for about $80 \mathrm{~m}$. In shape the esker is straight without any breaks and its ridge is sharp and uneven (Fig. 4).

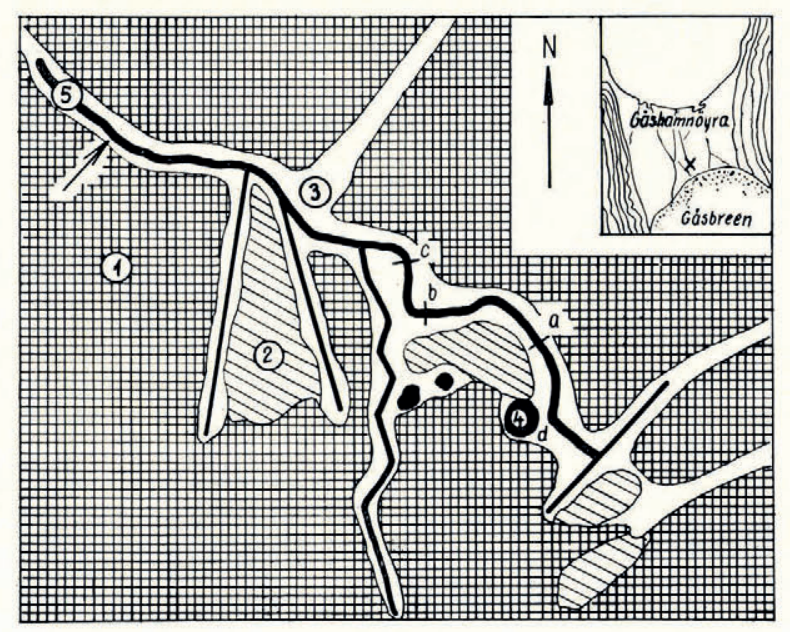

Fig. 2. Sketch map of the Gåshamnöyra area showing the situation of the eskers investigated. 1 . Moraine; 2. Kettles; 3. Channels ; 4. Kames; 5 . Eskers. The arrow indicates the longest esker; $a, b$ and $c$ are localities where sections were dug and where photographs were taken; $d$ indicates the kame from which the section in Figure 9 was drawn

The Gåshamnöyra and Bungebreen eskers are composed of sand and gravel. In the shorter and lower Gåshamnöyra eskers poorly sorted gravel-sized material predominates, while the longer and higher ones are composed mainly of sand and gravel (Figs. 5 and 6). The material also varies in certain sections across the same form. In the longest esker some parts consist of boulders, whereas others are composed either of sand or a sandy-gravelly mixture. The diversity in grain-sizes probably depends on the uniform distribution of the larger rock fragments within the ice mass.

In all the eskers sand and fine gravel are stratified but the bouldery material is not. The regularity in the stratification is not the same everywhere; it can be seen most clearly in the sandy parts of the eskers. An increase in the gravel-sized component results in a discontinuity of the layers, the individual sedimentation units are faulted and throughout the whole complex they present a less regular pattern.

In the cross-profile of one part of the largest esker (Fig. 7) there is a conspicuous inward bend of the layers. With depth the inclination of the layers increases and the deepest ones dip at $24-28^{\circ}$. No phenomena of this type occur in other parts of the same esker or in the other Gåshamnöyra eskers.

The inward dip of the layers may have resulted from the melting of ice beneath the esker and subsequent collapse of the material, a fact which may indicate an englacial origin of the esker. Observations on the ablation of glaciers show that the sediments resting on the ice surface, even though they may be more than $4 \mathrm{~m}$. thick, do not remain stationary during melting but begin to flow as the water supply increases. It is therefore doubtful whether an englacial formation resting on an unstable base of melting ice can possibly preserve its original form and structure after total melting of the ice. The Gåshamnöyra eskers are narrow and 


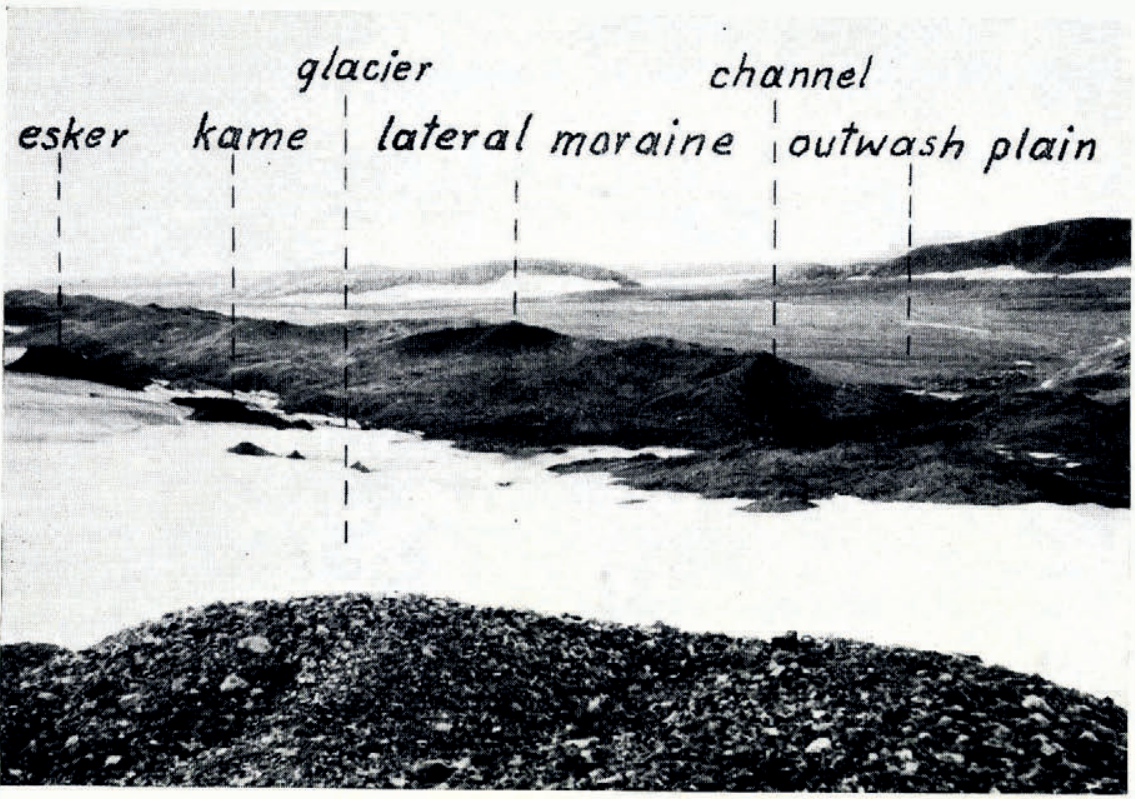

Fig. 3. A view of the western part of Bungebreen and the area immediately in front of the glacier

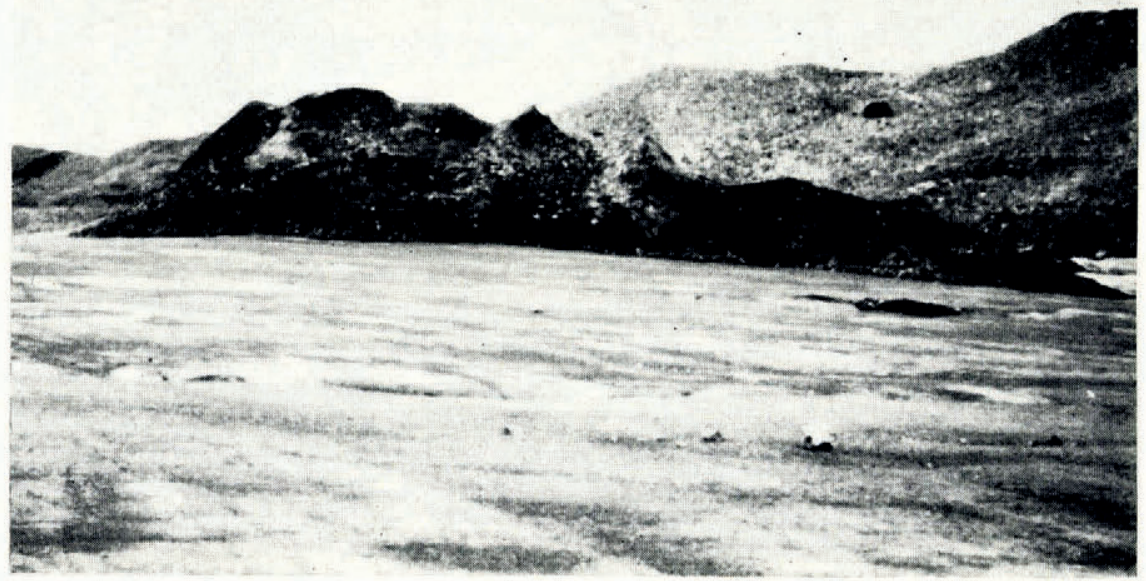

Fig. 4. An esker on Bungebreen. In the background is a ridge of the western lateral moraine 


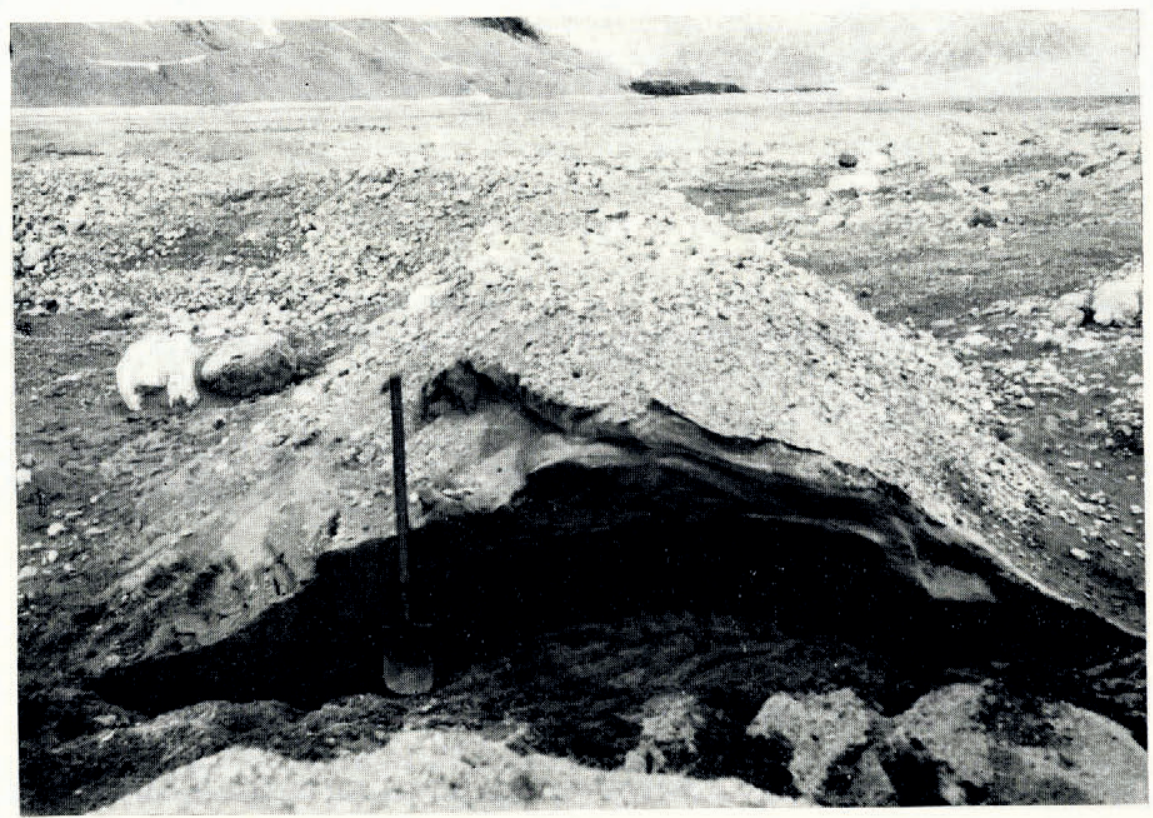

Fig. 5. The sandy part of an esker in Gashamnöyra viewed from the eastern side (" $a$ " in Figure 2). Its lower part is permanently frozen

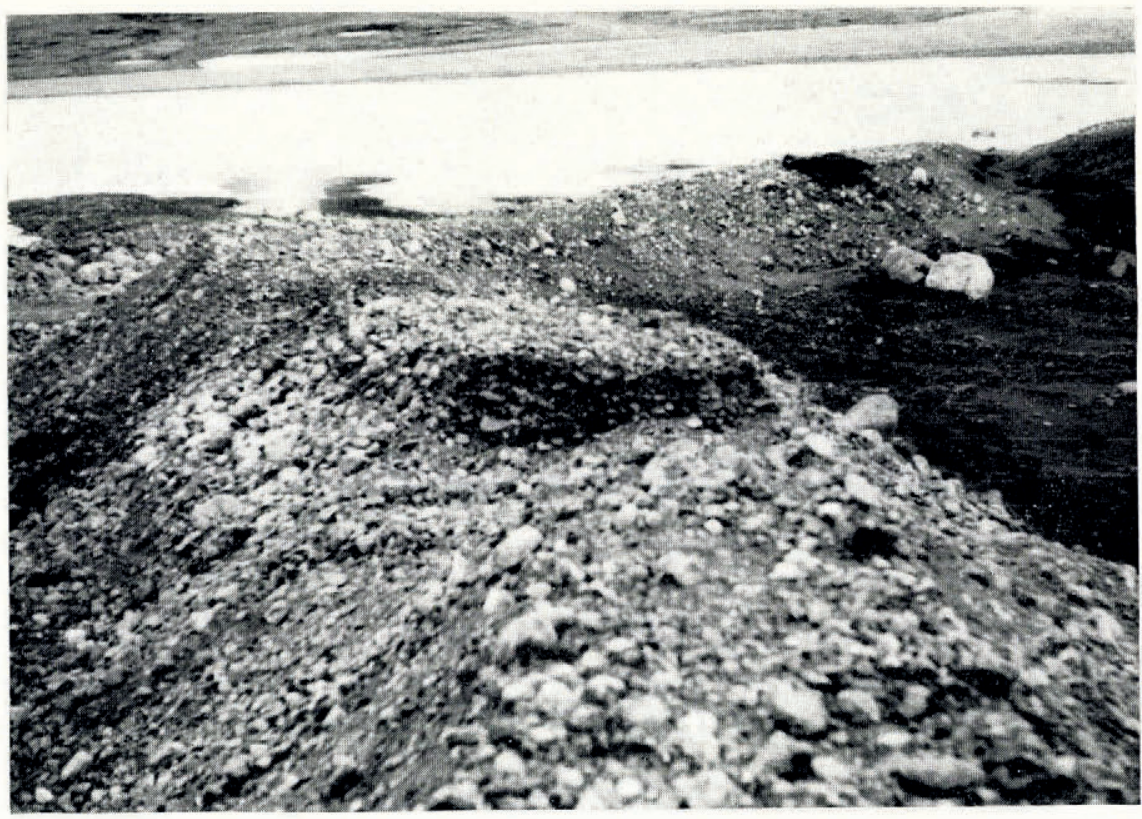

Fig. 6. The bouldery part of an esker in Gåshamnöyro vieu ea from the eastern side (" $b$ " in Figure 2). The boulders are about $30 \mathrm{~cm}$. in diameter 
melting of the underlying ice along their entire length would certainly have caused their deformation to have more diverse forms than the mere bending of the layers in a single part of the esker. Melting of the underlying ice would also have disturbed their shape. Yet, these eskers have the form of somewhat regular ridges. Hence, the englacial hypothesis is not satisfactory to account for the origin of the Gåshamnöyra eskers. It is preferable to assume that they formed in sub-glacier ice channels.

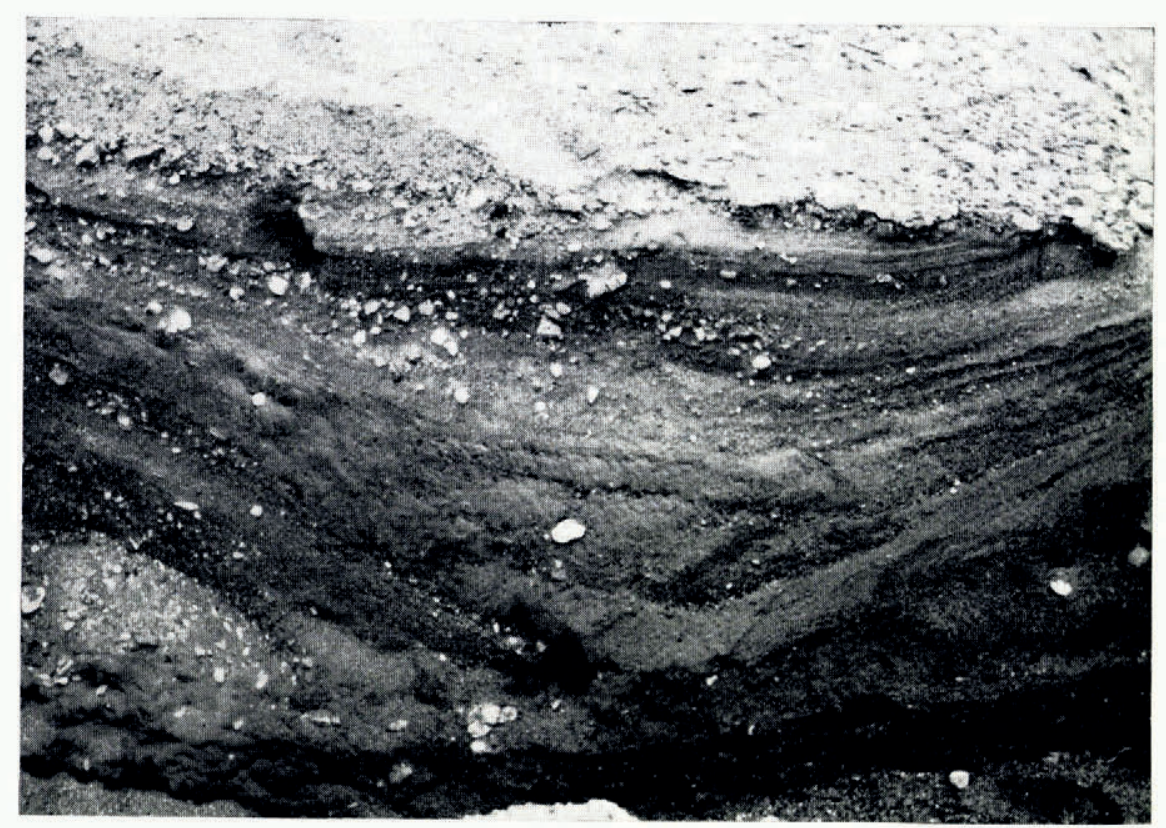

Fig. 7. The structure of an esker in Gåshamnöyra viewed from the eastern side (" $c$ " in Figure 2)

The material is well-sorted in the sand succession of the Gåshamnöyra esker. Approximately 80 per cent of the transported grains have a diameter of $0 \cdot \mathrm{I}-\mathrm{O} \cdot 4 \mathrm{~mm}$., whereas clay and silt amount to about 3 per cent. In several parts of the esker well-washed material is overlain by an unsorted succession of sand, gravel and pebbles. This diversity in the sorting of the deposits testifies to the wide range of intensity of the water current by which the eskers were built up. Evidence of rhythmic changes in the intensity of water flow is reflected in the stratified material. Rhythmic fluctuations in the force of the water flow result in a rhythmic alternation in the sediments. In the Gåshamnöyra eskers each sedimentary cycle terminates with sand. The commonest sedimentary pattern is an alternation of coarse gravels, fine gravels and sands.

In comparison with the Gåshamnöyra eskers, those of Bungebreen do not consist of separate sandy or bouldery parts. Instead of dipping to one side, the layers dip both proximally and distally.

In the area investigated kames are associated with eskers and they occur in close proximity to each other. In the Gåshamnöyra area the kames occur in groups and are separated from the largest esker by a kettle-like depression.

The Gåshamnöyra kames take the form of rounded mounds composed of stratified material. The base of each kame consists of a succession of pebbles overlain by sands and gravels. The gravel occurs as thin bands, whereas the sand layers have a considerable thickness and possess no lamination. The layers either thin out gradually or terminate abruptly (Fig. 8). 
The diameter of the base of the largest kame is $6 \mathrm{~m}$. and its height above the bottom of the depression is not more than $2 \mathrm{~m}$. Both the kames and eskers are being destroyed slowly by the action of melt water from Bungebreen.

The strike of the kame layers frequently changes in direction, thus forming a characteristic pattern that has not yet been observed in any other forms, either of fluvio-glacial or glacial origin (Fig. 9). The strike and dip pattern of the eskers, as shown in Figure 5, emphasizes the genetic individuality of the Gåshamnöyra eskers among fluvio-glacial forms. As the separate layers accumulated on the kame sides they dipped in various directions. The dip angles range from $8^{\circ}$ to $32^{\circ}$ but they do not exceed the maximum angle of repose.

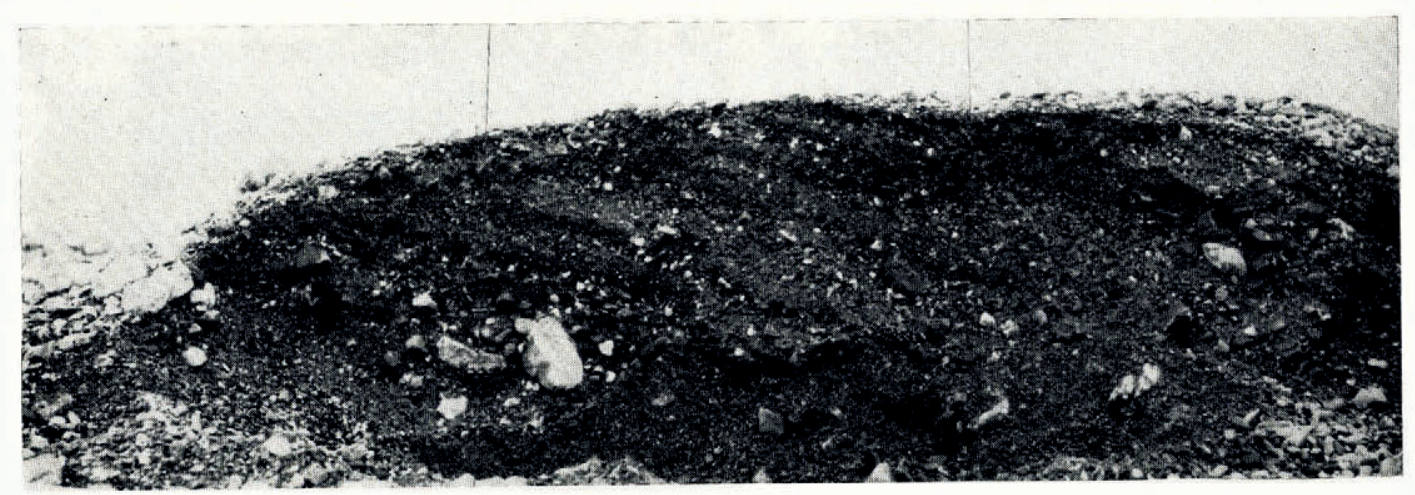

Fig. 8. The structure of a kame in Gåshamnöyra viewed from the southern side_(" $d$ " in Figure 2)

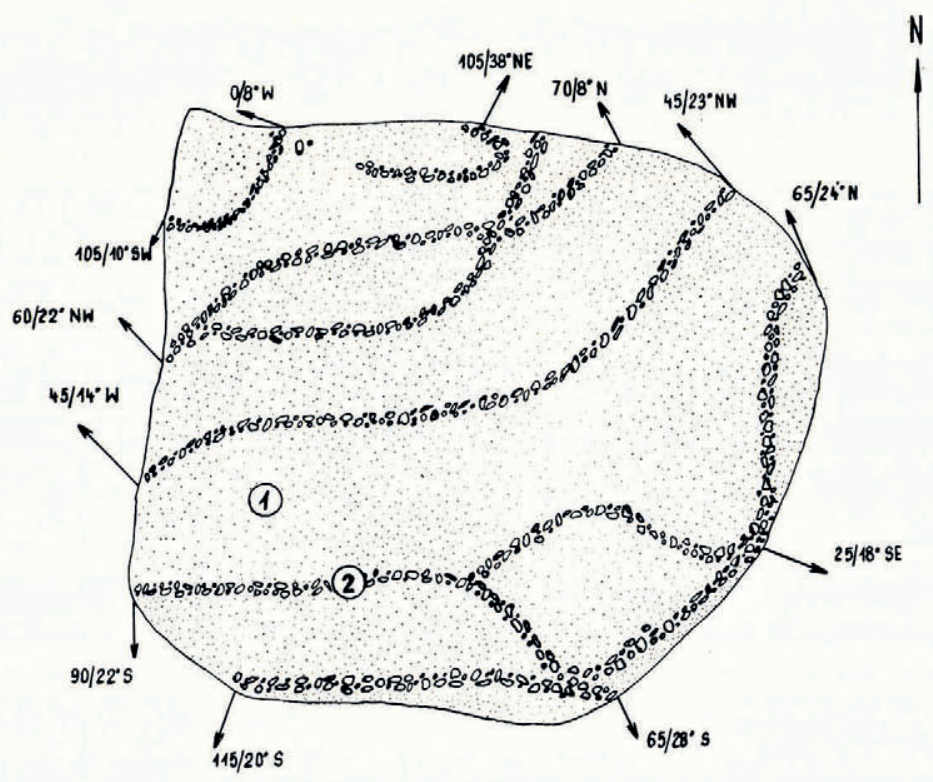

Fig. 9. A horizontal section through a kame in Gäshamnöyra (" $d$ " in Figure 2). The numbers round the margin of the diagram indicate the strike and dip values of the various layers; the dimensions of this kame are given in the text 
The fine material in the Gåshamnöyra kames is remarkably well sorted and it contains no clayey particles or silt. The main bulk of the kames consists of sands and gravels.

On Bungebreen both eskers and kames are at present emerging from the ice. Only their upper parts are visible and they protrude about $3 \mathrm{~m}$. above the ice surface. The kames lie in close proximity to a drainage channel (Fig. 3). They have the shape of mounds with sharppointed summits, but the depth of their bases is unknown. From the differences in height between the surface of the outwash plain, the lateral moraine and the kame, it can be inferred that the ice cover here is not very thick and that the bases of the kames are at the level of the glacier bedrock. The kames of Bungebreen possess similar structures to those of Gåshamnöyra.

In conclusion it can be stated that a morphological and structural analysis of the Gåshamnöyra eskers and kames, and those of Bungebreen, suggests that both of these forms originated subglacially.

MS. received 19 March 1964 and in revised form 29 January 1965 